\title{
Cytotoxic drugs in combination with the CXCR4 antagonist AMD3100 as a potential treatment option for pediatric rhabdomyosarcoma
}

\author{
STEPHAN REGENBOGEN $^{1}$, MATIAS JULIAN STAGNO ${ }^{1}$, SABINE SCHLEICHER $^{2}$, \\ KARIN SCHILBACH ${ }^{2}$, HANS BÖSMÜLLER ${ }^{3}$, JÖRG FUCHS ${ }^{1}$, EVI SCHMID $^{1 *}$ and GUIDO SEITZ ${ }^{1,4^{*}}$ \\ Departments of ${ }^{1}$ Pediatric Surgery and Pediatric Urology and ${ }^{2}$ Haematology and Oncology, University Children's Hospital; \\ ${ }^{3}$ Department of Pathology, University Hospital Tuebingen, D-72076 Tuebingen; ${ }^{4}$ Department of Pediatric Surgery, \\ University Children's Hospital, D-35043 Marburg, Germany
}

Received August 7, 2019; Accepted March 26, 2020

DOI: 10.3892/ijo.2020.5059

\begin{abstract}
Rhabdomyosarcoma (RMS) is the most common type of pediatric soft tissue sarcoma. The prognosis of advanced stage RMS remains poor, and metastatic invasion is a major cause of treatment failure. Therefore, there is an urgent need for treatment alternatives focusing on metastatic invasion and drug resistance. The stromal cell-derived factor-1 (SDF-1)/chemokine receptor 4 (CXCR4) axis is a crucial factor for metastatic invasion in RMS. Clinical data has revealed that high CXCR4 expression is associated with a poor outcome and a high metastatic rate in several malignancies, including RMS. Thus, targeting CXCR4 in addition to classical chemotherapy may improve the effectiveness of RMS treatment. In the present study, flow cytometry and reverse transcription-quantitative PCR were used to assess the effects of the combined treatment with a CXCR4 antagonist and chemotherapy on CXCR4 expression in the embryonal RMS (RME) cell line RD and in the alveolar RMS (RMA) cell line RH30. The functional effect of CXCR4 expression on the migratory behavior of RMS cells was analyzed using Transwell assays. Treatment with cytotoxic agents modulated CXCR4 expression in RMS cells in a dose-, drug- and cell line dependent manner; however, this was not observed in
\end{abstract}

Correspondence to: Dr Evi Schmid, Department of Pediatric Surgery and Pediatric Urology, University Children's Hospital, Hoppe-Seyler Straße 3, D-72076 Tuebingen, Germany

E-mail: evi.schmid@med.uni-tuebingen.de

"Contributed equally

Abbreviations: RMS, rhabdomyosarcoma; CXCR4, chemokine receptor 4; SDF-1, stromal cell-derived factor-1; RME, embryonal rhabdomyosarcoma; RMA, alveolar rhabdomyosarcoma; ALL, acute lymphoblastic leukemia; AML, acute myeloid leukemia

Key words: CXCR4, rhabdomyosarcoma, AMD3100, chemotherapeutic agents, doxorubicin, vincristine
RD cells with vincristine. The expression levels of CXCR4 significantly increased the migratory behavior of RMA and did not affect RME cell migration towards stromal cell-derived factor-1 $\alpha$ (SDF-1 $\alpha)$. AMD3100 markedly reduced the migration of RH30 cells in the Transwell assays compared with SDF- $1 \alpha$ alone, and the cytotoxic agents doxorubicin and vincristine increased this effect. The results of the combined treatment in RMS cells using the CXCR4 antagonist AMD3100 together with cytotoxic drugs demonstrated that this approach may be a promising alternative for the treatment of advanced stage pediatric RMS. The observed effects of circumventing metastatic invasion and drug resistance should be further investigated in vivo.

\section{Introduction}

Rhabdomyosarcoma (RMS) is the most common type of pediatric soft tissue sarcoma worldwide (1) and accounts for $7 \%$ of all pediatric malignant tumors (2). Embryonal RMS (RME) and alveolar RMS (RMA) are the two main histological subtypes; RME represents $\sim 70 \%$ and RMA $\sim 20 \%$ of all RMS cases (3). RME and gene fusion-negative RMA are known to be prognostically favorable, whereas paired box gene 3-forkhead (PAX3-FKHR) or PAX7-FKHR gene fusion-positive RMA frequently leads to metastatic progression (4-6), which is present in nearly $20 \%$ of RMS cases at time of diagnosis (7). Even with multimodal treatment, including systemic chemotherapy, surgery and/or radiotherapy, the prognosis of advanced stage RMS remains poor (8). Major treatment issues are metastatic invasion, local tumor recurrence and drug resistance (9). Several genes responsible for metastatic invasion have been identified in different types of cancer, including prostate, lung, breast and pancreatic cancer $(10,11)$. One of the genes of the metastatic cascade encodes the chemokine receptor 4 (CXCR4), a 7-transmembrane $\mathrm{G}$ protein-coupled receptor (12) that is upregulated in RMS cell lines as well as in lung, pancreatic and prostate tumors (13).

CXCR4 has been described as a marker of poor prognosis in acute lymphoblastic leukemia (ALL) and acute myeloid leukemia (AML) (14). A clinical study of 40 patients with RMS 
has demonstrated that high levels of CXCR4 are associated with unfavorable clinical features, bone marrow involvement and poor outcomes (15). In addition to its physiological role, multiple preclinical trials have demonstrated that CXCR4 and its ligand stromal cell-derived factor $1 \alpha$ (SDF-1 $\alpha)$ crucially influence metastatic invasion, proliferation and angiogenesis in different tumor types such as breast cancer (16), pancreatic cancer (17), colon cancer (18) and RMS (19-23). Chemotherapy appears to be involved in drug resistance and may promote metastasis by the induction of chemokines and chemokine receptor expression. Such metastasis promotion was observed in tumor models of melanoma $(24,25)$, head and neck (26), ovarian and breast cancer $(27,28)$.

Previous studies have demonstrated that the combination of chemotherapeutic drugs and CXCR4 inhibitors/antagonists such as AMD3100, AMD11070 and AMD3465 are successful treatments for various malignancies such as ALL $(29,30)$, AML (14) and prostate cancer (31). AMD3100 is a member of the bicyclam family, which was first identified as an antiretroviral small molecule and was demonstrated to bind selectively as an antagonist to CXCR4 (32,33). AMD3100 inhibited SDF-1 $\alpha$-induced HER2/Neu activation in vitro in breast cancer cells and modestly improved the overall survival of mice with metastatic ovarian cancer by inhibiting tumor growth in vivo (34-37). Additionally, AMD3100 has been reported to bind selectively as an antagonist to CXCR4, thus inhibiting the growth of ovarian cancer cells and intraperitoneal dissemination (38).

The aim of the present study was to evaluate the effects of different cytotoxic drugs on CXCR4 expression levels and to study the impact of a combination of CXCR4 inhibition and chemotherapy on the treatment of RMS in vitro.

\section{Materials and methods}

Cell lines and cell culture. The RMA cell line RH30 (ACC no. 489; DSMZ-German Collection of Microorganisms and Cell Cultures $\mathrm{GmbH}$ ) and the RME cell line RD (ATCC ${ }^{\circledR}$ CCL-136; American Type Culture Collection) were routinely cultured in DMEM (Biochrom, Ltd.) supplemented with $10 \%$ fetal bovine serum (FBS; Biochrom, Ltd.), $2 \mathrm{mM}$ L-glutamine, $50 \mathrm{U} / \mathrm{ml}$ penicillin and $50 \mu \mathrm{g} / \mathrm{ml}$ streptomycin (Biochrom, Ltd.). Mycoplasma-negative RMS cell lines were cultured in a humidified atmosphere incubator (BBD 6220; Heraeus Holding $\mathrm{GmbH}$ ) with $5 \% \mathrm{CO}_{2}$ at $37^{\circ} \mathrm{C}$.

Patient characteristics. The RMS tissues were collected by resection between January 2015 and January 2019 at the University Hospital of Tuebingen. Patients (3 female and 3 male) with histologically proven primary and/or recurrent rhabdomyosarcoma $(n=6)$ were prospectively recorded in this study. Diagnosis of rhabdomyosarcoma was histopathologically confirmed by the local Department of Pathology in Tuebingen as well as by the Reference Pathology (Institute of Pathology, University of Schleswig-Holstein, Kiel, Germany) of the Society for Paediatric Oncology and Haematology. The mean age of the patients was 26 months (range, 13-40 months). Written informed consent to participate in this study was obtained from the parents of all patients. This study was approved by the Ethical Committee of the Medical Faculty of the University Hospital Tuebingen (approval no. 354/2018A, amendment no. 354/2018B02).

Immunohistochemistry of CXCR4. Formalin-fixed and paraffin-embedded RMS specimens were cut into 4- $\mu \mathrm{m}$ sections and deparaffinized with xylol and ethanol (Carl Roth GmbH \& Co. KG). Standard and automated hematoxylin and eosin staining (Sakura Prisma, Sakura Finetek Germany $\mathrm{GmbH}$ ) at room temperature was performed for the evaluation of tumor tissue and areas of necrosis. For demasking the epitopes, samples were treated with hot citrate buffer $\left(100^{\circ} \mathrm{C} ; \mathrm{pH}\right.$ 6.0). Paraffin sections were then blocked with 3\% goat serum (Dako; Agilent Technologies, Inc.) and incubated overnight at $4{ }^{\circ} \mathrm{C}$ with mouse monoclonal anti-CXCR4 antibody (1:50; cat. no. sc-53534; Santa Cruz Biotechnology, Inc.). The following day, antibody binding was identified using VECTASTAIN Universal Elite ABC kit (LINARIS GmbH) and DAB solution (Dako; Agilent Technologies, Inc.). The slides were then analyzed using a transmitted light Zeiss Axioskop 40 microscope (Carl Zeiss AG; original magnification, $\mathrm{x} 100$ ).

Reagents, chemotherapeutics and antibodies. The CXCR4 antagonist AMD3100, also referred to as Plerixafor, was purchased from Sigma-Aldrich (Merck KGaA) and was pre-incubated for $30 \mathrm{~min}$ in all experiments before cytotoxic drug addition. CXCR4 mouse anti-human/CD184 antibody [clone 12G5; conjugated to allophycocyanin (APC); cat. no. 560936] was obtained from Becton, Dickinson and Company. Recombinant human SDF-1 $\alpha$ was purchased from ImmunoTools GmbH. Doxorubicin, vincristine and dactinomycin were obtained from the pharmacy of the University Hospital of Tuebingen. Paclitaxel was obtained from Enzo Life Sciences. The doses of cytotoxic agents used in the following experiments were $\mathrm{LD}_{40-80}$ of doxorubicin $(0.2 / 0.5 \mu \mathrm{g} / \mathrm{ml})$, vincristine $(0.001 / 0.0025 \mu \mathrm{g} / \mathrm{ml})$ and dactinomycin $(0.01 / 0.025 \mu \mathrm{g} / \mathrm{ml})$. For paclitaxel, 0.01 and $1 \mu \mathrm{g} / \mathrm{ml}$ was used in RH30 cells, and 0.01 and $0.1 \mu \mathrm{g} / \mathrm{ml}$ was used in RD cells.

Flow cytometry. The percentage of CXCR4-positive cells was measured by fluorescence-activated cell sorting (FACS). RMS cells RH30 and RD were seeded in a 6-well plate at a density of $1 \times 10^{5}$ cells/well and treated with or without cytotoxic drugs in the presence or absence of $10 \mu \mathrm{M}$ AMD3100 for $24 \mathrm{~h}$. After incubation, the adherent cells were collected by trypsinization, washed twice with PBS (Biochrom, Ltd.) and stained with CXCR4 mouse anti-human/CD184 antibody (1:100; cat. no. 560936; Becton, Dickinson and Company) for $30 \mathrm{~min}$ at room temperature in the dark. Subsequently, the cells were washed again with $200 \mu \mathrm{l}$ CellWASH solution (Becton, Dickinson and Company). The surface expression and the mean fluorescence intensity (MFI) of CXCR4 was analyzed using a BD FACS Canto II flow cytometer (Becton, Dickinson and Company) and evaluated with BD FACS Diva software v.8.0 (Becton, Dickinson and Company).

Reverse transcription-quantitative PCR (RT-qPCR). To evaluate the gene expression level of CXCR4, total RNA was isolated from RMS cells pretreated for $24 \mathrm{~h}$ with or without 
cytotoxic drugs using the RNeasy Plus Mini kit (Qiagen $\mathrm{GmbH}$ ) according to the manufacturer's instructions. cDNA synthesis was performed using the High-Capacity cDNA Reverse Transcription kit (Thermo Fisher Scientific, Inc.) according to the manufacturer's instructions. PCR amplification of the respective genes was performed in a total volume of $20 \mu \mathrm{l}$ using $40 \mathrm{ng}$ cDNA, $500 \mathrm{nM}$ forward and reverse primers and 2X GoTaq qPCR Master Mix (Promega Corporation) according to the manufacturer's protocol. The following amplification protocol was applied: $95^{\circ} \mathrm{C}$ for $5 \mathrm{~min}$, followed by 40 cycles of $60^{\circ} \mathrm{C}$ for $30 \mathrm{sec}$ and $72^{\circ} \mathrm{C}$ for $30 \mathrm{sec}$. The following primers were used: CXCR4 forward, 5'-GGTTCCTTCATGGAGTCATAGTC-3' and reverse, 5'-CGGTTACCATGGAGGGGATC-3'; and TATA-binding protein (TBP) forward, 5'-GCCCGAAACGCCGAATAT-3' and reverse, 5'-CCGTGGTTCGTGGCTCTC-3'. The specificity of the PCR amplicons was confirmed by analysis of the melting curves. For qPCR amplification and data analysis, CFX96 Real Time PCR Detection System (Bio-Rad Laboratories, Inc.) was used. To standardize gene expression and perform accurate RT-qPCR analysis, normalization relative to the consistently expressed housekeeping gene TBP was performed. Relative quantification of gene expression was calculated using the $\Delta \Delta \mathrm{Cq}$ method as previously described (39).

Transwell migration assay. Transwell migration assays were performed in 24-well plates (Corning, Inc.) using Transwell inserts with an $8-\mu \mathrm{m}$ pore size (Becton, Dickinson and Company). RMS cells were seeded into 6-well plates (Corning Inc.) at $5 \times 10^{5}$ cells/well and pretreated with or without $0.2 \mu \mathrm{g} / \mathrm{ml}$ doxorubicin, $0.001 \mu \mathrm{g} / \mathrm{ml}$ vincristine and/or $10 \mu \mathrm{M}$ AMD3100. After $24 \mathrm{~h}, 750 \mu \mathrm{l}$ of the culture medium with or without $300 \mathrm{ng} / \mathrm{ml}$ human recombinant SDF1- $\alpha$ was pipetted into the lower chambers of 24-well plates. Transwell inserts were placed into each well, and pretreated RH30 and RD cells were seeded into the upper chamber of the inserts at a density of $5 \times 10^{4}$ cells/well in culture medium without FBS. RMS cells were either treated or left untreated for $24 \mathrm{~h}$ and then cultured in a humidified atmosphere at $37^{\circ} \mathrm{C}$ with $5 \% \mathrm{CO}_{2}$. Subsequently, the inserts were moved to $4 \%$ paraformaldehyde (Carl Roth $\mathrm{GmbH} \& \mathrm{Co}$. KG), incubated for $15 \mathrm{~min}$ at room temperature, washed twice with PBS and stained with Giemsa (Sigma-Aldrich; Merck KGaA). The migrated cells bound to the lower surface of the membrane were counted with an inverted Axiovert 135 light microscope at magnification, x10 (Carl Zeiss AG) using three different areas of each membrane, and the mean was calculated with AxioVision Rel v.4.8 software (Carl Zeiss AG).

Evaluation of drug interaction. To evaluate the effect of the combination of AMD3100 with chemotherapeutic agents, the coefficient of drug interaction (CDI) was calculated as described by Foucquier and Guedj (40). According to the bliss independence model, which dissects additive from synergistic and antagonistic effects respectively, CDI was calculated by the formula $\mathrm{CDI}=[(\mathrm{A}+\mathrm{B})-(\mathrm{A} \times \mathrm{B})] / \mathrm{AB}$ where $\mathrm{AB}$ is the ratio of the absorbance in the combination of drugs vs. that of the control; and A or B is the ratio of the absorbance of the single agent group to that of the control group. CDI values $<1$,
$=1$ or $>1$ indicate that the drugs act in a synergistic, additive or antagonistic manner, respectively.

Western blotting. To analyze the total protein expression levels of CXCR4, 5x10 ${ }^{5}$ RH30 cells were seeded in 6-well plates and treated with or without $10 \mu \mathrm{M}$ AMD3100 for 24 h. RMS cells were next washed with ice-cold PBS and lysed with cell lysis buffer (Cell Signaling Technology, Inc.) on ice. The extracts were centrifuged at $4^{\circ} \mathrm{C}$ and $14,000 \mathrm{x} \mathrm{g}$ for $20 \mathrm{~min}$, and the protein concentration of the supernatant was determined by a Bradford assay. Protein samples $(30 \mu \mathrm{g})$ were subjected to $10 \%$ SDS-PAGE and transferred to a nitrocellulose membrane (VWR International $\mathrm{GmbH}$ ). Subsequently, the membranes were blocked for $1 \mathrm{~h}$ at room temperature with $10 \%$ non-fat dried milk (Carl Roth $\mathrm{GmbH} \& \mathrm{Co} . \mathrm{KG}$ ) in TBS (Sigma-Aldrich; Merck KGaA) containing $0.1 \%$ Tween-20 (Carl Roth GmbH \& Co. KG). For immunoblotting, the membranes were incubated overnight at $4^{\circ} \mathrm{C}$ with an antibody against CXCR4 (1:100; cat. no. ACR-014; Alomone Labs). Anti-GAPDH antibody (1:1,000; cat. no. 2118S; Cell Signaling Technology, Inc.) was used as a loading control. After incubation with a secondary anti-rabbit IgG antibody conjugated to horseradish peroxidase (1:3,000; cat. no. 7074S; Cell signaling Technology, Inc.), the proteins were visualized by the WesternSure ${ }^{\circledR}$ PREMIUM Chemiluminescent Substrate (LI-COR Biosciences). Specific bands were quantified with the Odyssey Fc Imaging System (LI-COR Biosciences), and the levels of CXCR4 protein were expressed as the ratio of signal intensity of the target protein relative to that of GAPDH.

Statistics. Data are expressed as the mean \pm standard error of the mean. All experiments were repeated at least three times. A Shapiro-Wilk test was performed to determine the normal distribution of the data. All data were tested for significance using an unpaired Student's t-test with Welch's correction or one-way ANOVA (with Bonferroni correction) using GraphPad Prism v.7.0 (GraphPad Software, Inc). P<0.05 was considered to indicate a statistically significant difference.

\section{Results}

Expression of CXCR4 in RMS cell lines. CXCR4 expression levels were analyzed in two RMS cell lines RH30 and RD by RT-qPCR and flow cytometry. The results of the flow cytometry assay demonstrated that $86.8 \%$ of the alveolar RMS cells (RH30) and $12.9 \%$ of the embryonal RMS cells (RD) were CXCR4-positive (Fig. 1A). RH30 cells exhibited significantly higher mean fluorescence intensity (MFI) values for CXCR4 compared with those in RD cells (Fig. 1B). RT-qPCR was performed to confirm this expression pattern. As illustrated in Fig. 1C, CXCR4 transcripts were detected by RT-qPCR in both RH30 and RD RMS cell lines and were present at significantly higher levels in RH30 cells compared with RD cells. In addition, immunohistochemical analysis of CXCR4 expression was performed in paraffin sections obtained from six recently diagnosed primary RMS cases; intense nuclear staining of CXCR4 was observed in RMS tissues, whereas lower intensity of CXCR4 was present in regular adjacent vascular structures (Fig. 1E). 

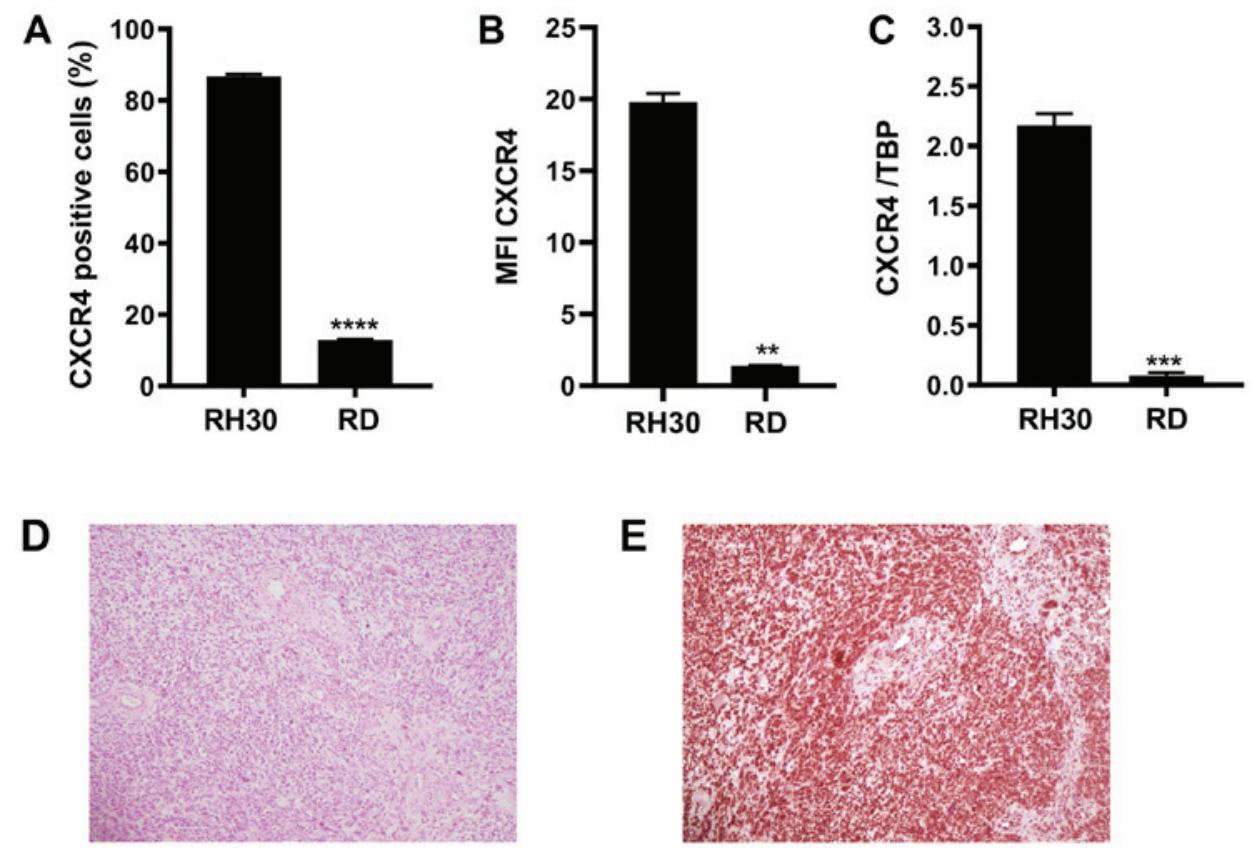

Figure 1. Analysis of CXCR4 expression in rhabdomyosarcoma cell lines and immunohistochemical staining of CXCR4 in RME. (A) Flow cytometric analysis of CXCR4 membrane expression (in \%; n=3). (B) Bar graphs represent the MFI of the flow cytometric analysis of CXCR4 (n=3). (C) mRNA level of CXCR4 relative to the housekeeping gene TBP in RH30 and RD cells (n=3). (D) Hematoxylin and eosin staining and (E) CXCR4 staining of RME paraffin sections. Original magnification, $x 100$. Error bars represent SEM. ${ }^{* *} \mathrm{P}<0.01,{ }^{* * *} \mathrm{P} \leq 0.001$ and ${ }^{* * * * *} \mathrm{P} \leq 0.0001$. RME, embryonal rhabdomyosarcoma; CXCR4, CXC chemokine receptor $4 \mathrm{MFI}$, mean fluorescence intensity; TBP, TATA-binding protein.

Effects of cytotoxic drugs in combination with the CXCR4 antagonist AMD3100. MTT assays were performed to obtain the dose-response curves and the corresponding $\mathrm{IC}_{50}$ values of chemotherapeutics in RD and RH30 cells (Fig. S1). In addition, further MTT assays were performed to evaluate the potential effects of the CXCR4 antagonist AMD3100, or the additive or synergistic effects of chemotherapeutic agents in combination with AMD3100. However, no significant effects of AMD3100 on RD or RH30 cells were observed, and no additive or synergistic effects were observed in RD or RH30 cells when combining chemotherapeutic agents with AMD3100 compared with the effects of the corresponding chemotherapeutic agents alone (Fig. S2).

CXCR4 expression after treatment with cytotoxic drugs. The present study next investigated whether the quantity of CXCR4 mRNA in RMS cells was sensitive to cytotoxic treatment.

As presented in Fig. 2, CXCR4 mRNA expression was significantly enhanced in the RH30 and RD cells after treatment with $0.5 \mu \mathrm{g} / \mathrm{ml}$ doxorubicin or $0.025 \mu \mathrm{g} / \mathrm{ml}$ dactinomycin compared with that in the untreated cells. Of note, vincristine and paclitaxel led to a significant downregulation of CXCR4 mRNA expression in RH30 cells compared with the untreated cells (Fig. 2C and G); however, this was not observed in RD cells (Fig. 2D and $\mathrm{H}$ ).

Flow cytometry analysis was utilized to confirm this expression pattern. Similar to the RT-qPCR results in Fig. 2, the number of CXCR4-positive cells and the MFI values in the two RMS cell lines increased significantly when treated with doxorubicin (Fig. 3A-a and B-a) and dactinomycin (Fig. 3A-c and B-c) compared with those in the control group. In addition, vincristine and paclitaxel also induced a significant reduction of CXCR4-positive cells and MFI values in RH30 cells compared with the untreated cells (Fig. 3A-b and A-d), in contrast to the results observed in RD cells (Fig. 3B-b and B-d).

Effects of AMD3100 treatment on CXCR4 expression. AMD3100 prevents the binding of the anti-CXCR4 antibody $12 \mathrm{G} 5$ in Jurkat and SUP-T1 cells $(41,42)$ as they bind the same epitope. The present study used this competitive binding to monitor AMD3100 binding to CXCR4 in RMS cell lines (43).

To investigate the optimal time and dose of AMD3100 binding, a competition assay with an anti-CXCR4 antibody (12G5 conjugated to APC) was performed by flow cytometry. The RH30 cell line was used due to its high levels of CXCR4 expression (Fig. 4). Compared with the untreated control, treatment with AMD3100 significantly reduced the binding of the anti-CXCR4 antibody to CXCR4 (Fig. 4A).

The effect of AMD3100 on CXCR4 protein expression was investigated by western blotting. AMD3100 exerted no effect on CXCR4 protein levels in RH30 cells (Fig. 4B).

Migratory response of RMS cells to chemotherapeutic agents in combination with AMD3100. Corroborating the previously reported findings, a significantly stronger migratory response to SDF-1 $\alpha(300 \mathrm{ng} / \mathrm{ml})$ was only observed in RH30 cells compared with that of the untreated control; by contrast, this was not observed in RD cells (Fig. 5A and B).

The functional impact of CXCR4 inhibition by AMD3100 alone and in combination with doxorubicin or vincristine on the migration of RMS cell lines was assessed using a Transwell migration assay. Treatment of RH30 cells, which exhibited high CXCR4 expression levels, with AMD3100 significantly reduced their migratory ability (Fig. 5C and E). This effect was not observed in RD cells, which have low levels of CXCR4 expression (Fig. 5D and F). 


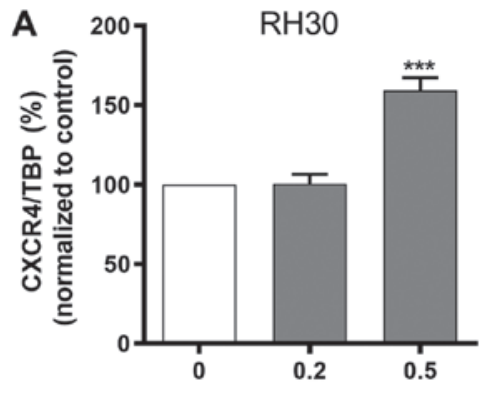

Doxorubicin $(\mu \mathrm{g} / \mathrm{ml})$

$$
\text { C }
$$

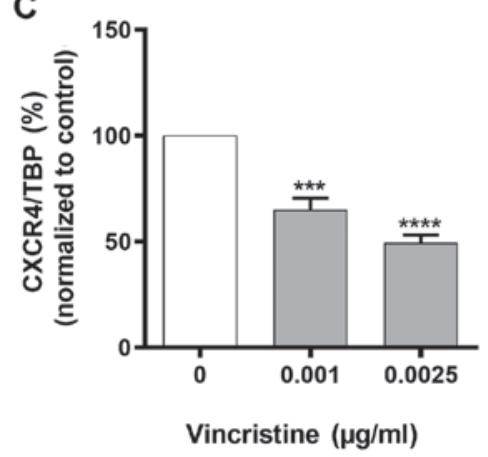

E

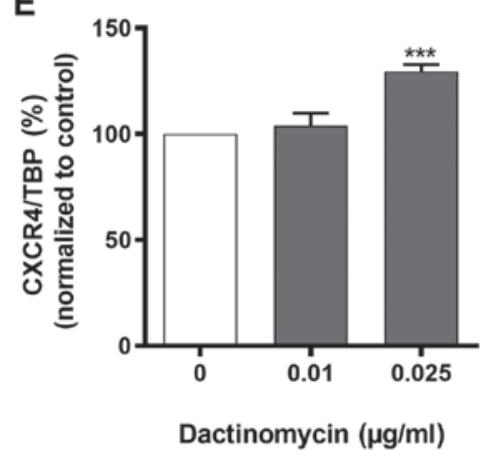

G

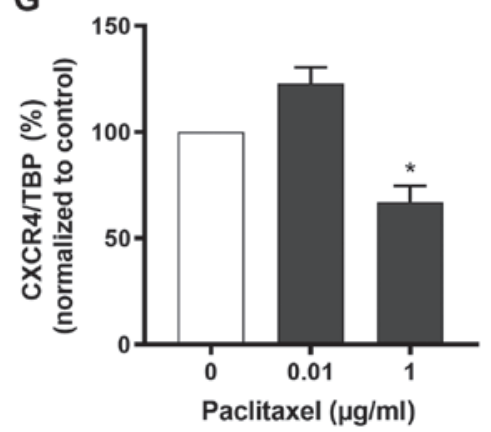

B

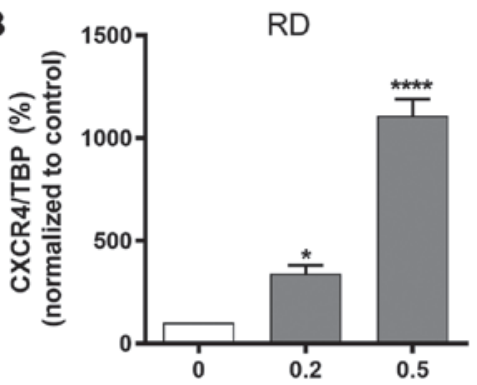

Doxorubicin $(\mu \mathrm{g} / \mathrm{ml})$

D

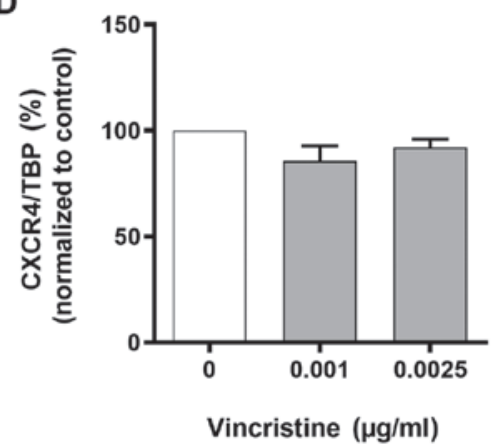

F

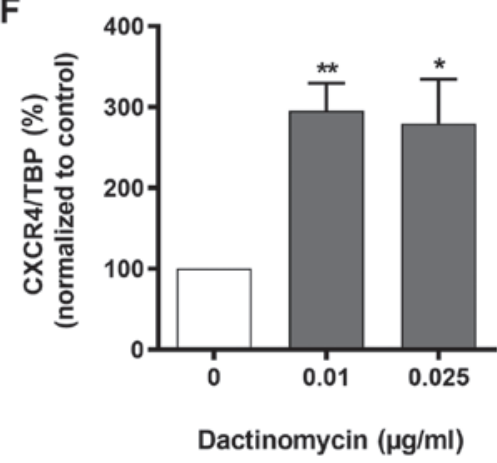

H

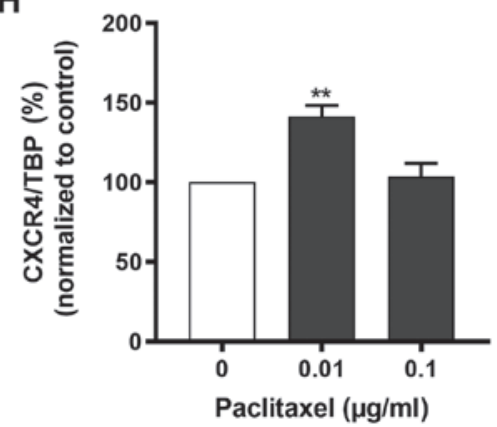

Figure 2. CXCR4 mRNA levels in RMS cells after chemotherapeutic agents' treatment. (A-F) CXCR4 mRNA expression levels were analyzed by reverse transcription-quantitative PCR in RMS cell lines RH30 (left) and RD (right) after $24 \mathrm{~h}$ of treatment with (A and B) 0.2 and $0.5 \mu \mathrm{g} / \mathrm{ml}$ doxorubicin (n=3), (C and D) 0.001 and $0.0025 \mu \mathrm{g} / \mathrm{ml}$ vincristine $(\mathrm{n}=4),(\mathrm{E}$ and $\mathrm{F}) 0.01$ and $0.025 \mu \mathrm{g} / \mathrm{ml}$ dactinomycin or $(\mathrm{G}$ and $\mathrm{H}) 0.01$ and $0.1 \mu \mathrm{g} / \mathrm{ml} \mathrm{paclitaxel}$ in $\mathrm{RD}$ cells and 0.01 and $1 \mu \mathrm{g} / \mathrm{ml}$ paclitaxel in RH30 cells $(\mathrm{n}=4)$. Error bars represent SEM. ${ }^{*} \mathrm{P}<0.05,{ }^{* *} \mathrm{P} \leq 0.01,{ }^{* * *} \mathrm{P} \leq 0.001,{ }^{* * * *} \mathrm{P} \leq 0.0001 \mathrm{vs}$. untreated control $(100 \%)$. CXCR4, CXC chemokine receptor 4; RMS, rhabdomyosarcoma; TBP, TATA-binding protein.

Doxorubicin significantly reduced the migration of RH30 cells compared with SDF-1 $\alpha$ treatment alone; this effect was amplified synergistically with the addition of AMD3100 (Fig. 5C). There was no change in the migration of RD cells with doxorubicin compared with SDF- $1 \alpha$ treatment alone; however, the combination of doxorubicin and AMD3100 led to a significant synergistic impairment of RD cell migration compared with SDF-1 $\alpha$ treatment alone (Fig. 5D).

The migration of RH30 cells was also significantly inhibited by vincristine compared with SDF-1 $\alpha$ treatment alone, and this effect was synergistically and significantly stronger 
A a
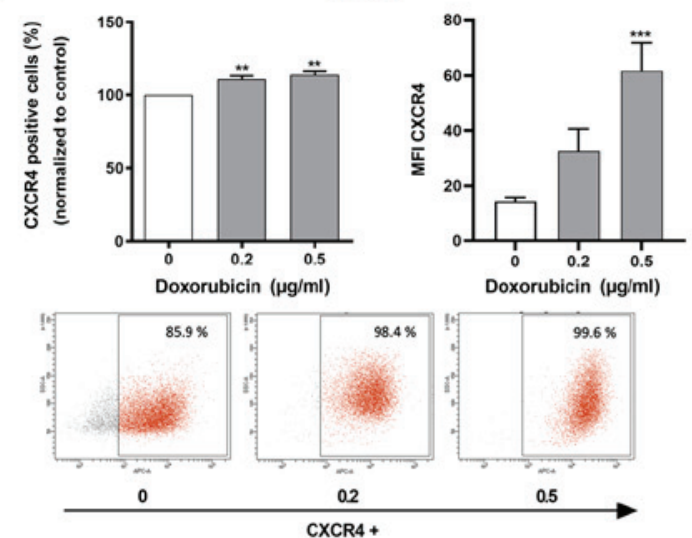

b

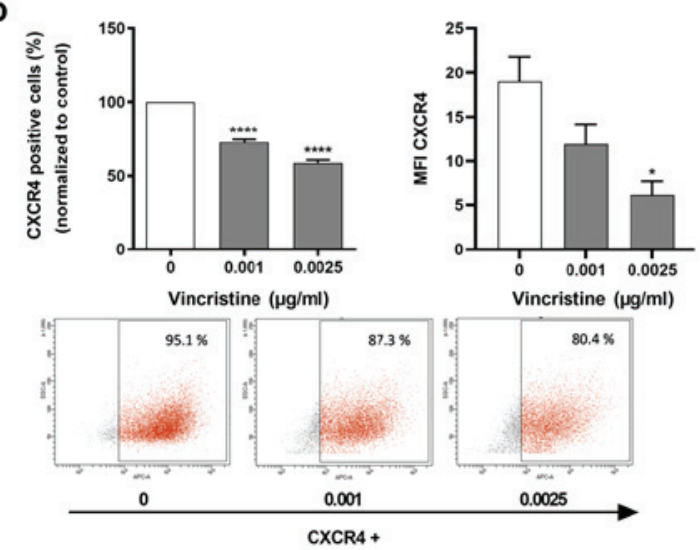

C
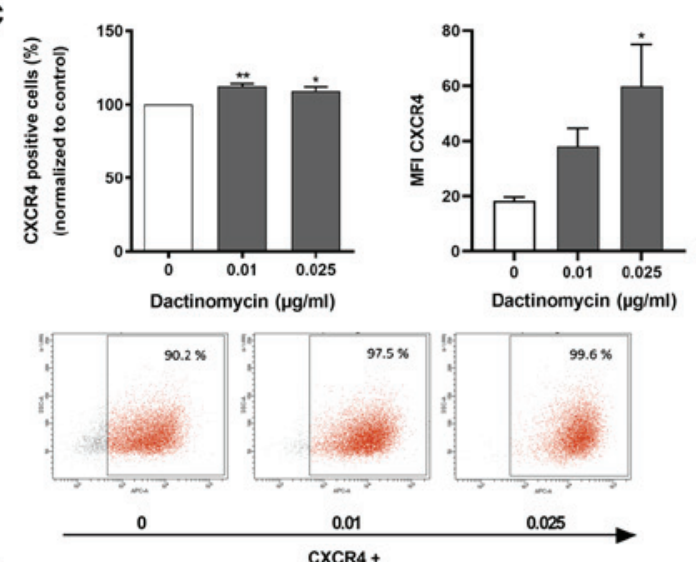

d
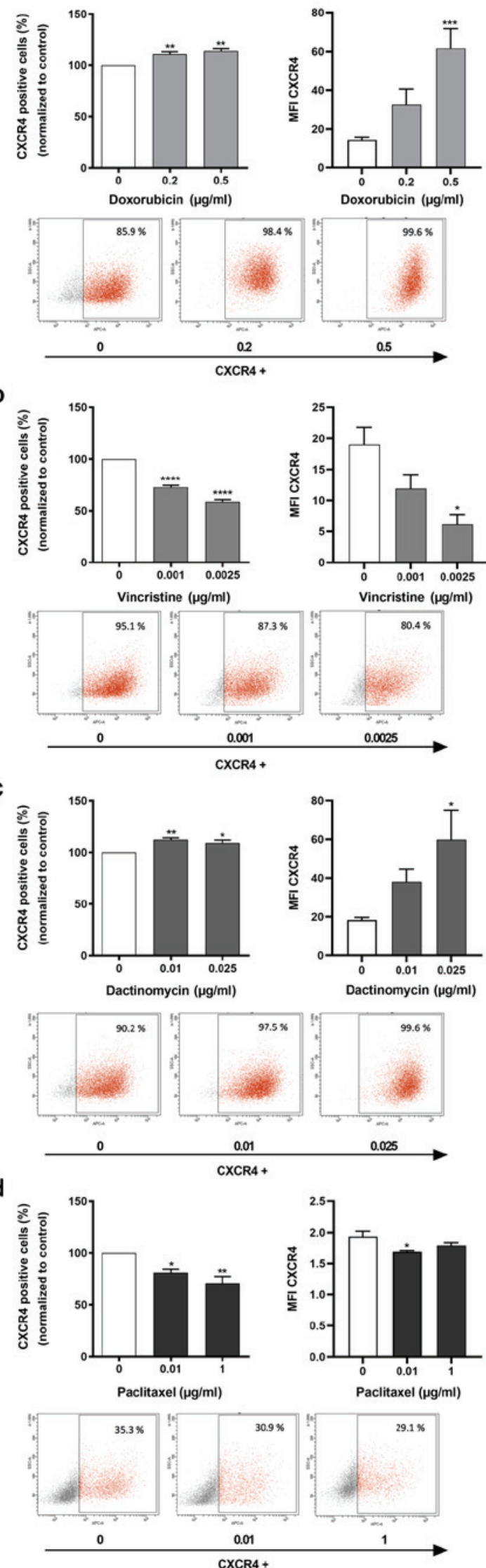

B a
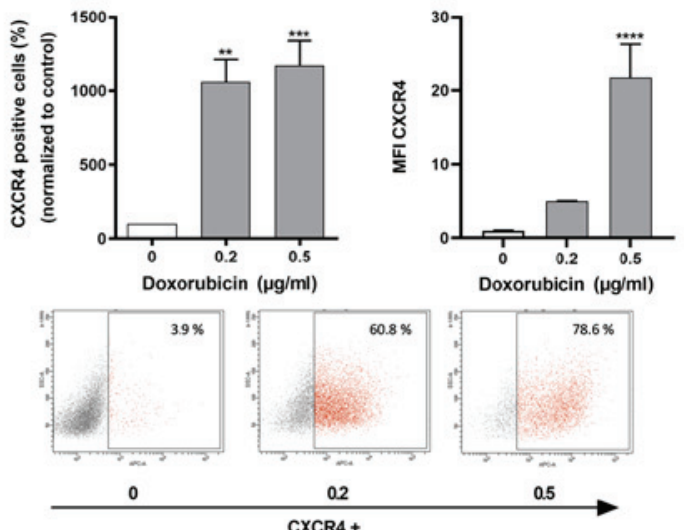

b
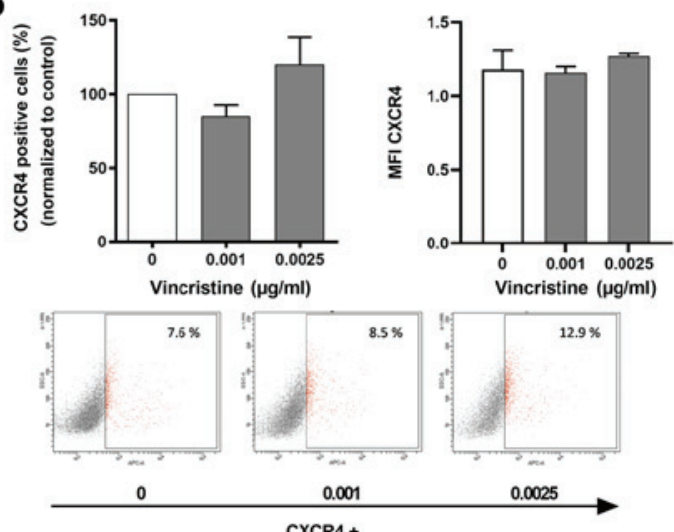

C
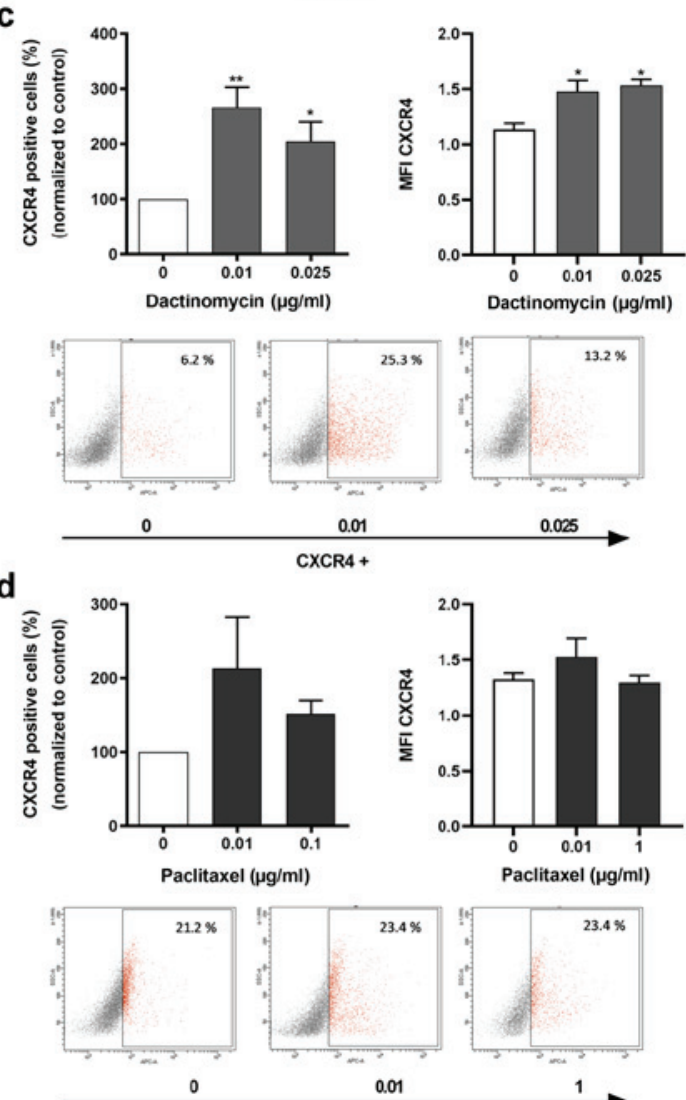

0

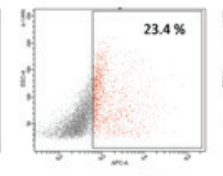

0.01

Figure 3. Flow cytometric analysis of CXCR4 in RMS cell lines after cytostatic treatment. (A and B) CXCR4-positive tumor cells (\%) and respective MFI for CXCR4 expression were evaluated for RMS cell lines (A) RH30 and (B) RD after a $24 \mathrm{~h}$ treatment with (a) $0,0.2$ and $0.5 \mu \mathrm{g} / \mathrm{ml}$ doxorubicin (n=4), (b) $0,0.001$ and $0.0025 \mu \mathrm{g} / \mathrm{ml}$ vincristine (n=5), (c) $0,0.01$ and $0.025 \mu \mathrm{g} / \mathrm{ml}$ dactinomycin (n=5) or (d) $0,0.01$ and $0.1 \mu \mathrm{g} / \mathrm{ml} \mathrm{paclitaxel}$ in RD cells and 0.01 and $1 \mu \mathrm{g} / \mathrm{ml}$ paclitaxel in RH30 cells $(\mathrm{n}=4)$. (a-d) Representative plots of CXCR4 expression are presented from one of five experiments under each graph. Error bars represent SEM. ${ }^{*} \mathrm{P}<0.05,{ }^{* *} \mathrm{P} \leq 0.01,{ }^{* * * *} \mathrm{P} \leq 0.001,{ }^{* * * * *} \mathrm{P} \leq 0.0001$ vs. the untreated control (100\%). CXCR4, CXC chemokine receptor 4 ; RMS, rhabdomyosarcoma; MFI, mean fluorescence intensity. 
A
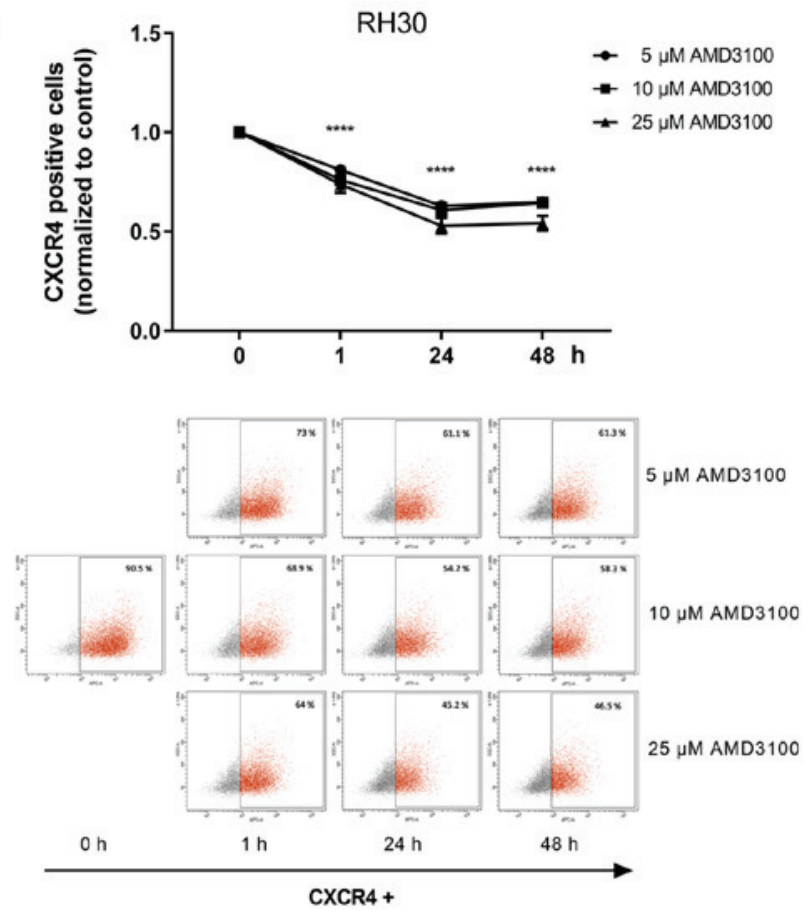

B
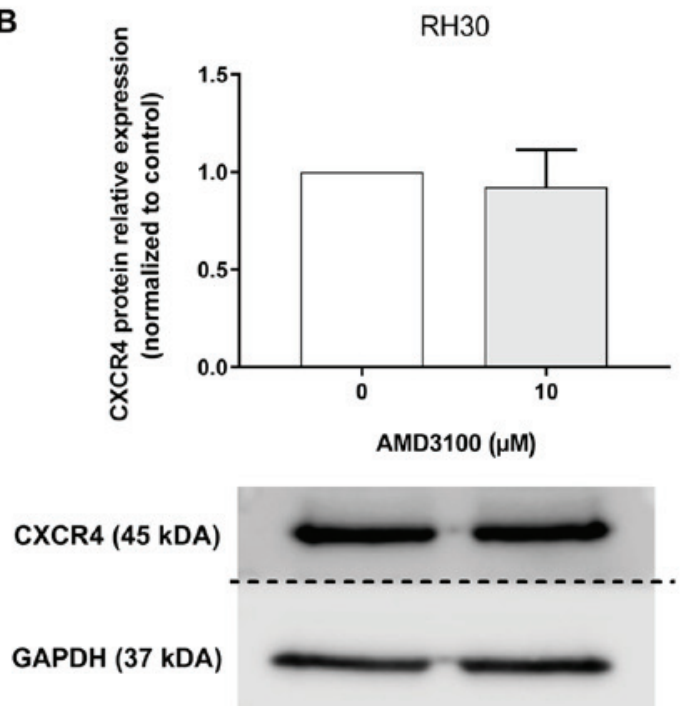

Figure 4. Binding capacity of AMD3100. (A) Analysis and representative dot blots of the binding of different doses of AMD3100 at different times in the RH30 cell line using flow cytometry in combination with a monoclonal CXCR4 antibody $(n=4)$. (B) Western blot analysis of total CXCR4 protein expression after $24-\mathrm{h}$ treatment with $10 \mu \mathrm{M}$ AMD3100 $(\mathrm{n}=3) .{ }^{* * * * *} \mathrm{P} \leq 0.0001$ vs. the untreated control (1). CXCR4, CXC chemokine receptor 4.

with the addition of AMD3100 (Fig. 5E). Vincristine alone or in combination with AMD3100 had no effect on the migration of RD cells (Fig. 5F).

Effects of AMD3100 treatment on clonal growth. The impact of the CXCR4 antagonist AMD3100 on tumor cell proliferation was quantified in colony forming assays. As presented in Fig. S3, the relative number of clones was significantly decreased in the presence of 10 and $15 \mu \mathrm{M}$ AMD3100 in the embryonal RMS cell line RD, but not in the alveolar RMS cell line RH30.

\section{Discussion}

The CXCR4-SDF1 $\alpha$ axis is involved in the migration and metastatic invasion of RMS cells in vitro (21-23). Emerging evidence suggests that CXCR4 also serves a decisive role in metastatic disease (44-47). CXCR4 expression levels are considered to be a prognostic marker for clinical outcome in soft tissue sarcoma (48). In RMS, high CXCR4 expression is associated with an aggressive alveolar subtype, unfavorable primary site, bone marrow infiltration and a poor clinical outcome (15). To improve this poor clinical prognosis, it is mandatory to understand the mechanisms influencing the metastatic behavior of these cells in the presence of cytotoxic agents and to investigate how chemotherapeutics regulate the CXCR4 receptor and how this affects RMS cell migration.

The present study examined how a combination therapy combining chemotherapy and CXCR4 modulation modulates CXCR4 expression and CXCR4-mediated migration. First, RT-qPCR and flow cytometry analysis were performed to assess the basal CXCR4 expression levels in RMA (RH30) and RME (RD) cell lines, and the results demonstrated that CXCR4 receptor expression was significantly higher in RH30 cells compared with that in RD cells. This is in agreement with previous studies, which have reported that CXCR4 expression levels are higher in alveolar compared with embryonal RMS cell lines $(22,49)$. Additionally, in a clinical series of 40 RMS cases, significantly higher expression of CXCR4 was identified in the alveolar subtype of RMS (15).

The effects of chemotherapeutic agents on the expression level of CXCR4 in RMS cells were subsequently analyzed. Both mRNA levels and membrane expression of CXCR4 were significantly enhanced under treatment with the topoisomerase II inhibitors doxorubicin and dactinomycin in the RMS cell lines RD and RH30 compared with the untreated control cells (50). The present study demonstrated for the first time that chemotherapeutics such as vincristine and paclitaxel induced a significant downregulation of CXCR4 at the mRNA and protein level in RMA cells, but not in RME cells. A possible explanation for this observation may be that chemotherapeutic drugs such as vincristine exert a destabilizing effect on microtubules and may prevent their depolymerization (51). Another explanation may be that vincristine and paclitaxel influence the stabilization of certain receptors or the membrane trafficking system; this needs to be clarified in detail in further studies. The upregulating effect of doxorubicin and dactinomycin is in accordance with previously published findings that chemotherapeutic agents can upregulate CXCR4 expression in different tumor models, such as pediatric AML, head and neck cancer and melanoma $(14,25,26,52)$.

Meta-analyses have reported that high CXCR4 expression levels are associated with a poor outcome/prognosis and high metastatic rates in breast cancer (46), lung cancer (53) and sarcoma $(47,54)$. CXCR4 has also been demonstrated to be involved in cell migration and invasion in soft tissue sarcoma (48). High levels of CXCR4 are associated with bone marrow involvement and poor outcome in RMS (15). Thus, increased chemokine receptor CXCR4 expression after cytotoxic treatment with doxorubicin and dactinomycin may represent a mechanism of therapy resistance and metastatic behavior in pediatric RMS. To gain an insight into this 
A

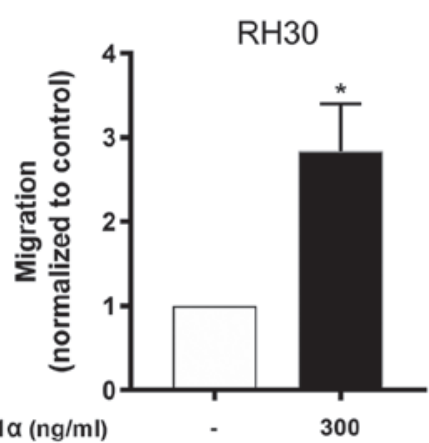

C

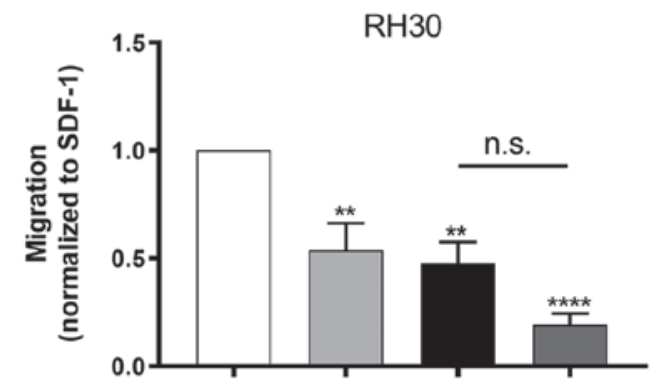

SDF-1 $(\mathrm{ng} / \mathrm{mI})$

AMD3100 $(\mu \mathrm{M})$

Doxorubicin $(\mu \mathrm{g} / \mathrm{ml})$

E

$\mathrm{RH} 30$

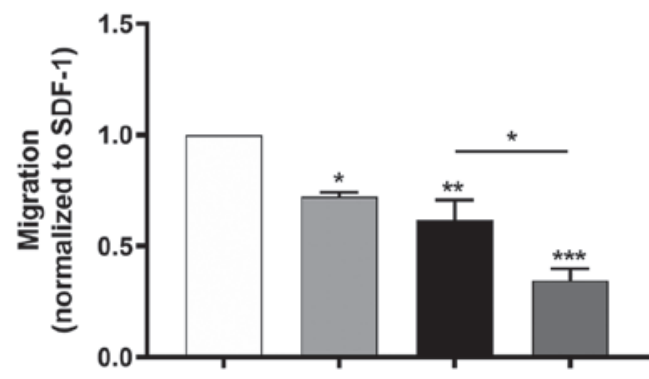

SDF-1 $\alpha(n g / m I)$

AMD3100 $(\mu \mathrm{M})$

Vincristine $(\mu \mathrm{g} / \mathrm{ml})$

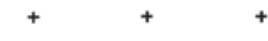

$+\quad+$

- +

$+\quad+$
B

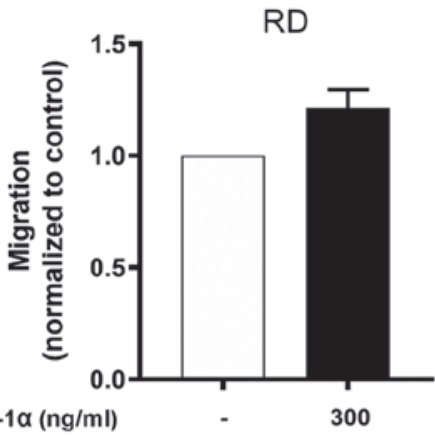

D

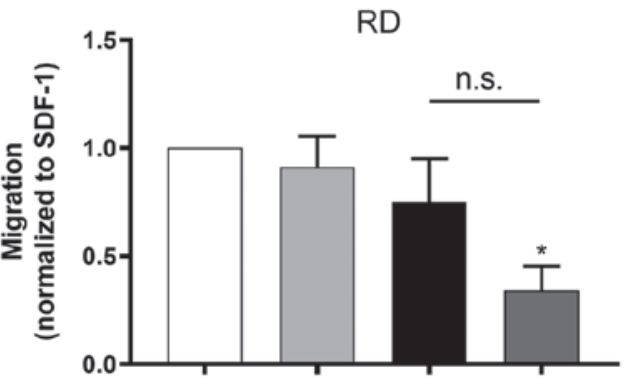

SDF-1 $\alpha(n g / m I)$

AMD3100 $(\mu \mathrm{M})$

Doxorubicin $(\mu \mathrm{g} / \mathrm{ml})$

F

$\mathrm{RD}$

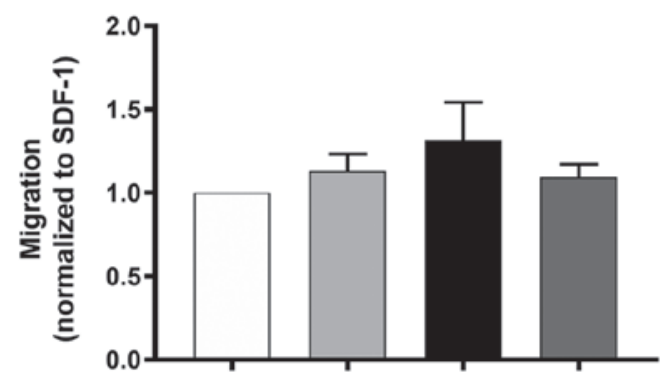

SDF-1 $(\mathrm{ng} / \mathrm{ml})$

AMD3100 $(\mu \mathrm{M})$

Vincristine $(\mu \mathrm{g} / \mathrm{ml})$

Figure 5. Migration of RMS cells in response to SDF-1 $\alpha$ and after preincubation with AMD3100, with or without chemotherapeutic agents. (A and B) Migration behavior of (A) RH30 and (B) RD cells in response to $300 \mathrm{ng} / \mathrm{ml} \mathrm{SDF}-1 \alpha(\mathrm{n}=5)$ relative to the control. (C-F) After preincubation with $10 \mu \mathrm{M}$ AMD3100 without or with (C and D) $0.2 \mu \mathrm{g} / \mathrm{ml}$ doxorubicin ( $\mathrm{n}=4-5)$ or $(\mathrm{E}$ and $\mathrm{F}) 0.001 \mu \mathrm{g} / \mathrm{ml}$ vincristine $(\mathrm{n}=3-4)$, RMS cells were stimulated with $300 \mathrm{ng} / \mathrm{ml} \mathrm{SDF}-1 \alpha$, and the changes in migration were recorded. The untreated control with SDF- $1 \alpha$ was set as 1 . Error bars represent $\mathrm{SEM}$. $\mathrm{P}<0.05,{ }^{* *} \mathrm{P} \leq 0.01,{ }^{* * *} \mathrm{P} \leq 0.001,{ }^{* * * *} \mathrm{P} \leq 0.0001$. RMS, rhabdomyosarcoma; SDF-1 $\alpha$, stromal cell-derived factor-1 $\alpha$.

mechanism, Transwell assays were performed in the present study, and the migratory behavior of RH30 and RD cells in response to SDF1 $\alpha$ was studied. SDF-1 $\alpha$, a selective ligand of CXCR4, serves a pivotal role in the metastatic behavior of tumor cells that express high levels of CXCR4 (21). In accordance with the study by Tarnowski et al (55), the results of the present study confirmed a significant chemotactic response to SDF-1 $\alpha$ in RMA (RH30) cells compared with that of cells in control medium devoid of SDF-1 $\alpha$. This effect was not observed in RME (RD) cells. CXCR4 expression can be induced by the fused oncoproteins PAX3-FKHR, which are strongly expressed in RMA but not in RME cells (56), leading to enhanced migration and adhesion (22). This finding was supported by the present study. Furthermore, significantly reduced cell migration following treatment with the CXCR4 antagonist AMD3100 was observed in RH30 cells, but not in RME cells compared with the untreated controls. As previously described (22), these results may be attributed to the high CXCR4 levels of RMA cells and the low CXCR4 expression in RME cells. 
The functional impact of CXCR4 modulation on the migration of RMS cell lines was evaluated in the present study using AMD3100 alone and in combination with doxorubicin or vincristine. The migration of RMA cells that were pre-treated with vincristine or doxorubicin was significantly decreased by AMD3100, whereas the migration of RME cells towards the medium containing SDF- $1 \alpha$ was not significantly influenced by AMD3100. Similar to these results, the study by Sison et al (14) demonstrated that the chemotherapeutic agents cytarabine, daunorubicin, etoposide and methotrexate led to an enhanced expression of CXCR4 in the leukemia cell lines MOLM-14, MV4-11 and 697. These authors also demonstrated an enhanced SDF-1 $\alpha$ mediated chemotaxis of MOLM-14 cells treated with cytarabine (14). In the present study on RMS cells, all the tested chemotherapeutic agents reduced SDF-1 $\alpha$-induced migration of RMA cells. The reason for this difference may be that Sison et al (14) only analyzed viable (annexin-negative) leukemic cells. The present study did not exhibit increased RMA cell migration induced by chemotherapeutic drugs possibly due to methodical reasons or due to the fact that the biological behavior of RMS cells cannot be compared with that of leukemic cells. Another potential explanation may be the impact of a different chemokine receptor CXCR7. CXCR7 is expressed in RMS cells, is encoded on the same chromosome as CXCR4 (23) and has a greater affinity for SDF-1 $\alpha$ (57). Kalatskaya et al (32) has revealed that AMD3100 also functions as an agonist for CXCR7. Further studies regarding the assessment of chemotherapeutic treatment on CXCR7 expression in conjunction with $\mathrm{CXCR} 4$ are needed to reveal new aspects of the role of the CXCR4-CXCR7-SDF-1 $\alpha$ axis.

The results of the present study demonstrated for the first time that doxorubicin and vincristine in combination with AMD3100 markedly reduced the migration of RMA cells compared with the control cells. In the RME cell line RD, this effect could only be accomplished with doxorubicin. This was in line with a previous study on an ALL mouse model, which reported that the combination of AMD11070 and vincristine resulted in lower numbers of leukemic cells in the bloodstream and higher overall survival rates compared with the effects of monotherapy with vincristine (29). In small cell lung cancer, only the combination of chemotherapy and AMD3100 exhibited anti-metastatic effects (58).

Of note, AMD3100 exerted different effects on the proliferation and clonogenicity in embryonic RMS cells RD compared with those in alveolar RMS cells RH30. The reason why these tumor cell lines exhibited different susceptibility to growth reduction by a CXCR4 antagonist may be due to their different subtypes. Although RD cells express significantly lower levels of CXCR4 on their surface, their growth response is significantly more affected by AMD3100 compared with that of RH30 cells, which have higher expression levels of the CXCR4 receptor. On the other hand, CXCR4 and CXCR7 levels are (counter-) balanced with CXCR7, exhibiting a higher affinity for SDF-1 $\alpha$ compared with CXCR4. Since AMD3100 can bind to CXCR7, high expression of CXCR7 may account for the reduced growth rate of RD cells $(32,57)$.

It has previously been demonstrated that AMD3100, a reversible inhibitor of CXCR4, binds to the SDF-1 $\alpha$ binding site of CXCR4 and thus prevents the binding of the anti-CXCR4 antibody $12 \mathrm{G} 5(29,59)$. The present study also observed a reduced number of CXCR4-positive cells after AMD3100 treatment compared with untreated cells in the flow cytometry experiments. However, this was not reflected by the reduced CXCR4 protein levels in AMD3100-treated cells detected by western blotting. This suggested that a reduction of CXCR4-positive cells reflected impaired anti-CXCR4 antibody binding at the receptor site occupied by AMD3100 or downregulation of the surface receptor, leading to an increased concentration of CXCR4 intracellularly while maintaining stable protein content.

Previous studies have suggested that in RMS, as in other tumor entities, in addition to the blockade of CXCR4, inhibition of CXCR7 is also important in the regulation of angiogenesis, stem cell trafficking and mediating organ-specific metastases of cancer (60). The genes for CXCR7 and CXCR4 are both located on chromosome 2q37.3, and CXCR7 and CXCR4 share ligand specificity for SDF-1 $\alpha$, suggesting that a functional synergy of the two receptors is likely (61-63). In addition, the CXCR4 antagonist AMD3100 increases CXCR7 expression $(32,52)$. The migration data from the present study, however, suggested that factors other than SDF-1 $\alpha$ may also modulate/contribute to the migratory behavior of RMS cells, since doxorubicin increased CXCR4 receptor expression but reduced migration in RH30 cells, whereas vincristine decreased both CXCR4 expression and migratory behavior in the same tumor cell line. By contrast, in RD cells, both chemotherapeutic drugs did not change the migratory behavior.

The sheer expression level of chemokine receptors may not necessarily be associated with functionality, as membrane-expressed receptors such as CXCR4 have been identified to be functionally inactive $(64,65)$. This functionality has been investigated in detail with regard to its role in migratory behavior (66). Thus, further investigations are necessary to identify and illuminate factors that control, regulate and modulate the CXCR4-CXCR7-SDF-1 $\alpha$ axis in (RMS) tumor cells.

As demonstrated by Guo et al (12), not only epigenetic and transcriptional, but also autocrine mechanisms serve a role in the regulation of CXCR4/SDF-1 $\alpha$ expression. In the present study, all the investigated cytostatic drugs modulated the expression levels of CXCR4 in RMS cells. However, a number of other factors are known to also have a modulatory effect on CXCR4 expression (67); these include nuclear respiratory factor 1 (68), specificity protein 1 (69), Serum- and glucocorticoid-inducible kinase 3 and Spartin activate atrophin-1-interacting protein $4(70,71)$ as well as hypoxia $(56,72,73)$. It would therefore be of great interest to investigate in more detail the chemotherapeutic effects on the factors that control CXCR4 expression and turnover. In vivo studies may also help clarify the hierarchy and interplay of the factors that control CXCR4 expression in sarcomas and may identify targets for therapeutic options.

Considering the results of the present study and the published data, intensification of pharmacological therapy by inhibition of CXCR4 with AMD3100 is a promising approach in the treatment of pediatric RMS. This treatment may be particularly advantageous for advanced stages of RMS regarding metastasis and drug resistance. Thus, low CXCR4 expression levels achieved through a combination of chemotherapeutic agents with AMD3100 may help decrease cancer cell migration, which lowers the risk of tumor recurrence. Further studies will be necessary to translate these promising results into preclinical trials. 


\section{Acknowledgements}

The authors would like to thank Mrs. Bettina Kirchner, Mrs. Melanie Hauth and Mrs. Julia Wenz (Department of Pediatric Surgery and Pediatric Urology, University Hospital Tuebingen) for technical support, Mr. Olaf Kupka and Mrs. Stefanie Saile (IT Department, University Hospital Tuebingen) for IT support and Mrs. Vanessa Di Cecco (McMaster University) for her support as a native speaker.

\section{Funding}

This study was supported by the Kind-Philipp-Foundation, Donors' Association for German Science e.V. grant (to SR).

\section{Availability of data and materials}

All data generated or analyzed during this study are included in this published article.

\section{Authors' contributions}

SR and MJS conducted the experiments. SR, MJS, HB, SS and ES analyzed the data. SR and ES designed the study. ES, SS, KS, and GS drafted the manuscript. All authors read and approved the final manuscript.

\section{Ethics approval and consent to participate}

This study was approved by the Ethical Committee of the Medical Faculty of the University Hospital Tuebingen (approval no. 354/2018A, amendment no. 354/2018B02). Written informed consent to participate in this study was obtained from the parents of all patients.

\section{Patient consent for publication}

Not applicable.

\section{Competing interests}

The authors declare that they have no competing interests.

\section{References}

1. Ognjanovic S, Linabery AM, Charbonneau B and Ross JA: Trends in childhood rhabdomyosarcoma incidence and survival in the United States, 1975-2005. Cancer 115: 4218-4226, 2009.

2. Skapek SX, Ferrari A, Gupta AA, Lupo PJ, Butler E, Shipley J, Barr FG and Hawkins DS: Rhabdomyosarcoma. Nat Rev Dis Primers 5: 1, 2019.

3. Rudzinski ER, Anderson JR, Hawkins DS, Skapek SX, Parham DM and Teot LA: The World Health Organization Classification of Skeletal Muscle Tumors in Pediatric Rhabdomyosarcoma: A report from the children's oncology group. Arch Pathol Lab Med 139: 1281-1287, 2015.

4. Davicioni E, Anderson MJ, Finckenstein FG, Lynch JC, Qualman SJ, Shimada H, Schofield DE, Buckley JD, Meyer WH, Sorensen PH, et al: Molecular classification of rhabdomyosarcoma--genotypic and phenotypic determinants of diagnosis: A report from the Children's Oncology Group. Am J Pathol 174: 550-564, 2009

5. Egas-Bejar D and Huh WW: Rhabdomyosarcoma in adolescent and young adult patients: Current perspectives. Adolesc Health Med Ther 5: 115-125, 2014.
6. Dagher R and Helman L: Rhabdomyosarcoma: An overview. Oncologist 4: 34-44, 1999.

7. Oberlin O, Rey A, Lyden E, Bisogno G, Stevens MC, Meyer WH, Carli M and Anderson JR: Prognostic factors in metastatic rhabdomyosarcomas: Results of a pooled analysis from United States and European cooperative groups. J Clin Oncol 26: 2384-2389, 2008.

8. Perkins SM, Shinohara ET, DeWees T and Frangoul H: Outcome for children with metastatic solid tumors over the last four decades. PLoS One 9: e100396, 2014.

9. Herrmann D, Seitz G, Fuchs J and Armeanu-Ebinger S: Susceptibility of rhabdomyosarcomacellstomacrophage-mediated cytotoxicity. OncoImmunology 1: 279-286, 2012.

10. Steeg PS: Tumor metastasis: Mechanistic insights and clinical challenges. Nat Med 12: 895-904, 2006.

11. Gupta GP and Massagué J: Cancer metastasis: Building a framework. Cell 127: 679-695, 2006.

12. Guo F, Wang Y, Liu J, Mok SC, Xue F and Zhang W: CXCL12/CXCR4: A symbiotic bridge linking cancer cells and their stromal neighbors in oncogenic communication networks. Oncogene 35: 816-826, 2016.

13. Chatterjee S, Behnam Azad B and Nimmagadda S: The intricate role of CXCR4 in cancer. Adv Cancer Res 124: 31-82, 2014.

14. Sison EA, McIntyre E, Magoon D and Brown P: Dynamic chemotherapy-induced upregulation of CXCR4 expression: A mechanism of therapeutic resistance in pediatric AML. Mol Cancer Res 11: 1004-1016, 2013.

15. Diomedi-Camassei F, McDowell HP, De Ioris MA, Uccini S, Altavista P, Raschellà G, Vitali R, Mannarino O, De Sio L, Cozzi DA, et al: Clinical significance of CXC chemokine receptor-4 and c-Met in childhood rhabdomyosarcoma. Clin Cancer Res 14: 4119-4127, 2008.

16. Müller A, Homey B, Soto H, Ge N, Catron D, Buchanan ME, McClanahan T, Murphy E, Yuan W, Wagner SN, et al: Involvement of chemokine receptors in breast cancer metastasis. Nature 410: 50-56, 2001.

17. Wang Z, Ma Q, Liu Q, Yu H, Zhao L, Shen S and Yao J: Blockade of SDF-1/CXCR4 signalling inhibits pancreatic cancer progression in vitro via inactivation of canonical Wnt pathway. Br J Cancer 99: 1695-1703, 2008.

18. Zeelenberg IS, Ruuls-Van Stalle L and Roos E: The chemokine receptor CXCR4 is required for outgrowth of colon carcinoma micrometastases. Cancer Res 63: 3833-3839, 2003.

19. Domanska UM, Kruizinga RC, Nagengast WB, Timmer-Bosscha $H$, Huls G, de Vries EG and Walenkamp AM: A review on CXCR4/CXCL12 axis in oncology: No place to hide. Eur J Cancer 49: 219-230, 2013

20. Kucia M, Jankowski K, Reca R, Wysoczynski M, Bandura L, Allendorf DJ, Zhang J, Ratajczak J and Ratajczak MZ: CXCR4-SDF-1 signalling, locomotion, chemotax is and adhesion. J Mol Histol 35: 233-245, 2004.

21. Strahm B, Durbin AD, Sexsmith E and Malkin D: The CXCR4-SDF1alpha axis is a critical mediator of rhabdomyosarcoma metastatic signaling induced by bone marrow stroma. Clin Exp Metastasis 25: 1-10, 2008.

22. Libura J, Drukala J, Majka M, Tomescu O, Navenot JM, Kucia M, Marquez L, Peiper SC, Barr FG, Janowska-Wieczorek A, et al: CXCR4-SDF-1 signaling is active in rhabdomyosarcoma cells and regulates locomotion, chemotaxis, and adhesion. Blood 100: 2597-2606, 2002.

23. Grymula K, Tarnowski M, Wysoczynski M, Drukala J, Barr FG, Ratajczak J, Kucia M and Ratajczak MZ: Overlapping and distinct role of CXCR7-SDF-1/ITAC and CXCR4-SDF-1 axes in regulating metastatic behavior of human rhabdomyosarcomas. Int J Cancer 127: 2554-2568, 2010.

24. Lev DC, Onn A, Melinkova VO, Miller C, Stone V, Ruiz M, McGary EC, Ananthaswamy HN, Price JE and Bar-Eli M: Exposure of melanoma cells to dacarbazine results in enhanced tumor growth and metastasis in vivo. J Clin Oncol 22: 2092-2100, 2004.

25. Kim M, Koh YJ, Kim KE, Koh BI, Nam DH, Alitalo K, Kim I and Koh GY: CXCR4 signaling regulates metastasis of chemoresistant melanoma cells by a lymphatic metastatic niche. Cancer Res 70: 10411-10421, 2010.

26. Muller A, Sonkoly E, Eulert C, Gerber PA, Kubitza R, Schirlau K, Franken-Kunkel P, Poremba C, Snyderman C, Klotz LO, et al: Chemokine receptors in head and neck cancer: Association with metastatic spread and regulation during chemotherapy. Int J Cancer 118: 2147-2157, 2006.

27. Ratajczak MZ, Jadczyk T, Schneider G, Kakar SS and Kucia M: Induction of a tumor-metastasis-receptive microenvironment as an unwanted and underestimated side effect of treatment by chemotherapy or radiotherapy. J Ovarian Res 6: 95, 2013. 
28. Shaked Y, Henke E, Roodhart JM, Mancuso P, Langenberg MH, Colleoni M, Daenen LG, Man S, Xu P, Emmenegger U, et al: Rapid chemotherapy-induced acute endothelial progenitor cell mobilization: Implications for antiangiogenic drugs as chemosensitizing agents. Cancer Cell 14: 263-273, 2008.

29. Parameswaran R, Yu M, Lim M, Groffen J and Heisterkamp N: Combination of drug therapy in acute lymphoblastic leukemia with a CXCR4 antagonist. Leukemia 25: 1314-1323, 2011.

30. Juarez J, Bradstock KF, Gottlieb DJ and Bendall LJ: Effects of inhibitors of the chemokine receptor CXCR4 on acute lymphoblastic leukemia cells in vitro. Leukemia 17: 1294-1300, 2003.

31. Domanska UM, Timmer-Bosscha H, Nagengast WB, Oude Munnink TH, Kruizinga RC, Ananias HJ, Kliphuis NM, Huls G, De Vries EG, de Jong IJ, et al: CXCR4 inhibition with AMD3100 sensitizes prostate cancer to docetaxel chemotherapy. Neoplasia 14: 709-718, 2012

32. Kalatskaya I, Berchiche YA, Gravel S, Limberg BJ, Rosenbaum JS and Heveker N: AMD3100 is a CXCR7 ligand with allosteric agonist properties. Mol Pharmacol 75: 1240-1247, 2009.

33. De Clercq E: Potential clinical applications of the CXCR4 antagonist bicyclam AMD3100. Mini Rev Med Chem 5: 805-824, 2005 .

34. Kajiyama H, Shibata K, Terauchi M, Ino K, Nawa A and Kikkawa F: Involvement of SDF-1alpha/CXCR4 axis in the enhanced peritoneal metastasis of epithelial ovarian carcinoma. Int J Cancer 122: 91-99, 2008.

35. Smith MC, Luker KE, Garbow JR, Prior JL, Jackson E, Piwnica-Worms D and Luker GD: CXCR4 regulates growth of both primary and metastatic breast cancer. Cancer Res 64 8604-8612, 2004.

36. Cabioglu N, Summy J, Miller C, Parikh NU, Sahin AA, Tuzlali S, Pumiglia K, Gallick GE and Price JE: CXCL-12/stromal cell-derived factor-1alpha transactivates HER2-neu in breast cancer cells by a novel pathway involving Src kinase activation. Cancer Res 65: 6493-6497, 2005.

37. Li YM, Pan Y, Wei Y, Cheng X, Zhou BP, Tan M, Zhou X, Xia W, Hortobagyi GN, Yu D, et al: Upregulation of CXCR4 is essential for HER2-mediated tumor metastasis. Cancer Cell 6: 459-469, 2004

38. Ray P, Lewin SA, Mihalko LA, Schmidt BT, Luker KE and Luker GD: Noninvasive imaging reveals inhibition of ovarian cancer by targeting CXCL12-CXCR4. Neoplasia 13: 1152-1161, 2011.

39. Schmid E, Stagno MJ, Yan J, Stournaras C, Lang F, Fuchs J and Seitz G: Store-operated $\mathrm{Ca}(2+)$ entry in rhabdomyosarcoma cells. Biochem Biophys Res Commun 477: 129-136, 2016

40. Foucquier J and Guedj M: Analysis of drug combinations: Current methodological landscape. Pharmacol Res Perspect 3 : e00149, 2015

41. Schols D, Struyf S, Van Damme J, Esté JA, Henson G and De Clercq E: Inhibition of T-tropic HIV strains by selective antagonization of the chemokine receptor CXCR4. J Exp Med 186: 1383-1388, 1997.

42. Poty S, Désogère P, Goze C, Boschetti F, D'huys T, Schols D, Cawthorne C, Archibald SJ, Maëcke HR and Denat F: New AMD3100 derivatives for CXCR4 chemokine receptor targeted molecular imaging studies: Synthesis, anti-HIV-1 evaluation and binding affinities. Dalton Trans 44: 5004-5016, 2015.

43. Stamatopoulos B, Meuleman N, De Bruyn C, Pieters K, Mineur P, Le Roy C, Saint-Georges S, Varin-Blank N, Cymbalista F, Bron D, et al: AMD3100 disrupts the cross-talk between chronic lymphocytic leukemia cells and a mesenchymal stromal or nurse-like cell-based microenvironment: Pre-clinical evidence for its association with chronic lymphocytic leukemia treatments. Haematologica 97: 608-615, 2012.

44. Zlotnik A: New insights on the role of CXCR4 in cancer metastasis. J Pathol 215: 211-213, 2008.

45. Wang J, Loberg R and Taichman RS: The pivotal role of CXCL12 (SDF-1)/CXCR4 axis in bone metastasis. Cancer Metastasis Rev 25: 573-587, 2006.

46. Zhang Z, Ni C, Chen W, Wu P, Wang Z, Yin J, Huang J and Qiu F: Expression of CXCR4 and breast cancer prognosis: A systematic review and meta-analysis. BMC Cancer 14: 49, 2014.

47. Laverdiere C, Hoang BH, Yang R, Sowers R, Qin J, Meyers PA, Huvos AG, Healey JH and Gorlick R: Messenger RNA expression levels of CXCR4 correlate with metastatic behavior and outcome in patients with osteosarcoma. Clin Cancer Res 11: 2561-2567, 2005.

48. Kim RH, Li BD and Chu QD: The role of chemokine receptor CXCR4 in the biologic behavior of human soft tissue sarcoma. Sarcoma 2011: 593708, 2011
49. Jankowski K, Kucia M, Wysoczynski M, Reca R, Zhao D, Trzyna E, Trent J, Peiper S, Zembala M, Ratajczak J, et al: Both hepatocyte growth factor (HGF) and stromal-derived factor-1 regulate the metastatic behavior of human rhabdomyosarcoma cells, but only HGF enhances their resistance to radiochemotherapy. Cancer Res 63: 7926-7935, 2003.

50. Marinello J, Delcuratolo M and Capranico G: Anthracyclines as topoisomerase II poisons: From early studies to new perspectives. Int J Mol Sci 19: 19, 2018

51. Mukhtar E, Adhami VM and Mukhtar H: Targeting microtubules by natural agents for cancer therapy. Mol Cancer Ther 13: 275-284, 2014.

52. Sison EA, Magoon D, Li L, Annesley CE, Rau RE, Small D and Brown P: Plerixafor as a chemosensitizing agent in pediatric acute lymphoblastic leukemia: Efficacy and potential mechanisms of resistance to CXCR4 inhibition. Oncotarget 5: 8947-8958, 2014.

53. Liang JX, Gao W, Liang Y and Zhou XM: Chemokine receptor CXCR4 expression and lung cancer prognosis: A meta-analysis. Int J Clin Exp Med 8: 5163-5174, 2015

54. Li YJ, Dai YL, Zhang WB, Li SJ and Tu CQ: Clinicopathological and prognostic significance of chemokine receptor CXCR4 in patients with bone and soft tissue sarcoma: A meta-analysis. Clin Exp Med 17: 59-69, 2017.

55. Tarnowski M, Grymula K, Liu R, Tarnowska J, Drukala J, Ratajczak J, Mitchell RA, Ratajczak MZ and Kucia M: Macrophage migration inhibitory factor is secreted by rhabdomyosarcoma cells, modulates tumor metastasis by binding to CXCR4 and CXCR7 receptors and inhibits recruitment of cancer-associated fibroblasts. Mol Cancer Res 8: 1328-1343, 2010

56. Tarnowski M, Grymula K, Reca R, Jankowski K, Maksym R, Tarnowska J, Przybylski G, Barr FG, Kucia M and Ratajczak MZ: Regulation of expression of stromal-derived factor-1 receptors: CXCR4 and CXCR7 in human rhabdomyosarcomas. Mol Cancer Res 8: 1-14, 2010

57. Cheng X, Wang H, Zhang X, Zhao S, Zhou Z, Mu X, Zhao C and Teng W: The Role of SDF-1/CXCR4/CXCR7 in Neuronal Regeneration after Cerebral Ischemia. Front Neurosci 11: 590, 2017.

58. Taromi S, Kayser G, Catusse J, von Elverfeldt D, Reichardt W, Braun F, Weber WA, Zeiser R and Burger M: CXCR4 antagonists suppress small cell lung cancer progression. Oncotarget 7: 85185-85195, 2016.

59. De Clercq E: Inhibition of HIV infection by bicyclams, highly potent and specific CXCR4 antagonists. Mol Pharmacol 57: 833-839, 2000

60. Sun X, Cheng G, Hao M, Zheng J, Zhou X, Zhang J, Taichman RS, Pienta KJ and Wang J: CXCL12 / CXCR4 / CXCR7 chemokine axis and cancer progression. Cancer Metastasis Rev 29: 709-722, 2010.

61. Balabanian K, Lagane B, Infantino S, Chow KY, Harriague J, Moepps B, Arenzana-Seisdedos F, Thelen M and Bachelerie F: The chemokine SDF-1/CXCL12 binds to and signals through the orphan receptor RDC1 in T lymphocytes. J Biol Chem 280: 35760-35766, 2005.

62. Burns JM, Summers BC, Wang Y, Melikian A, Berahovich R, Miao Z, Penfold ME, Sunshine MJ, Littman DR, Kuo CJ, et al: A novel chemokine receptor for SDF-1 and I-TAC involved in cell survival, cell adhesion, and tumor development. J Exp Med 203: 2201-2213, 2006

63. Heesen M, Berman MA, Charest A, Housman D, Gerard C and Dorf ME: Cloning and chromosomal mapping of an orphan chemokine receptor: Mouse RDC1. Immunogenetics 47: 364-370, 1998

64. Mitra P, De A, Ethier MF, Mimori K, Kodys K, Shibuta K, Mori M, Madison JM, Miller-Graziano C and Barnard GF: Loss of chemokine SDF-1alpha-mediated CXCR4 signalling and receptor internalization in human hepatoma cell line HepG2. Cell Signal 13: 311-319, 2001.

65. Honczarenko M, Douglas RS, Mathias C, Lee B, Ratajczak MZ and Silberstein LE: SDF-1 responsiveness does not correlate with CXCR4 expression levels of developing human bone marrow B cells. Blood 94: 2990-2998, 1999.

66. Rabin RL, Park MK, Liao F, Swofford R, Stephany D and Farber JM: Chemokine receptor responses on T cells are achieved through regulation of both receptor expression and signaling. J Immunol 162: 3840-3850, 1999.

67. Busillo JM and Benovic JL: Regulation of CXCR4 signaling. Biochim Biophys Acta 1768: 952-963, 2007.

68. Moriuchi M, Moriuchi H, Turner W and Fauci AS: Cloning and analysis of the promoter region of CXCR4, a coreceptor for HIV-1 entry. J Immunol 159: 4322-4329, 1997. 
69. Wegner SA, Ehrenberg PK, Chang G, Dayhoff DE, Sleeker AL and Michael NL: Genomic organization and functional characterization of the chemokine receptor CXCR4, a major entry co-receptor for human immunodeficiency virus type 1. J Biol Chem 273: 4754-4760, 1998.

70. Marchese A, Raiborg C, Santini F, Keen JH, Stenmark H and Benovic JL: The E3 ubiquitin ligase AIP4 mediates ubiquitination and sorting of the $\mathrm{G}$ protein-coupled receptor CXCR4. Dev Cell 5: 709-722, 2003.

71. Slagsvold T, Marchese A, Brech A and Stenmark H: CISK attenuates degradation of the chemokine receptor CXCR4 via the ubiquitin ligase AIP4. EMBO J 25: 3738-3749, 2006.
72. Schioppa T, Uranchimeg B, Saccani A, Biswas SK, Doni A, Rapisarda A, Bernasconi S, Saccani S, Nebuloni M, Vago L, et al: Regulation of the chemokine receptor CXCR4 by hypoxia. J Exp Med 198: 1391-1402, 2003

73. Wang X, Li C, Chen Y, Hao Y, Zhou W, Chen C and Yu Z: Hypoxia enhances CXCR4 expression favoring microglia migration via HIF-1alpha activation. Biochem Biophys Res Commun 371: 283-288, 2008. 